\title{
SOME CLINICAL-THERAPEUTIC FEATURES OF ALCOHOL ENCEPHALOPATHIES
}

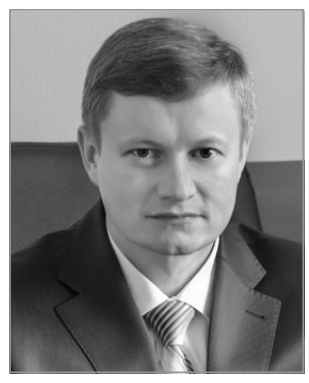

V. I. Ponomaryov

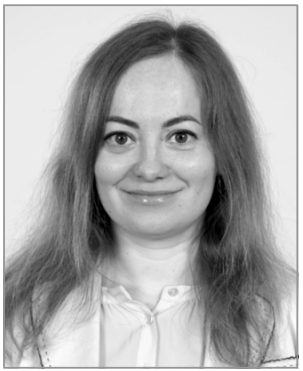

T. M. Roshchupkina

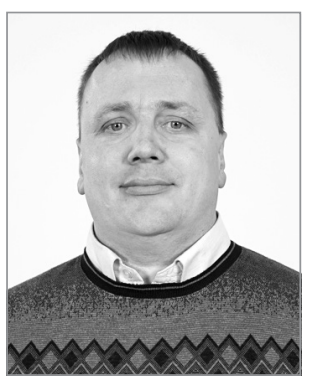

0. M. Mishchenko

(C) Volodymyr Ponomaryov (Ukraine) - Doctor of Medicine, Professor, Head of the Department of Psychiatry, Narcology, Neurology and Medical Psychology of School of Medicine, V.N. Karazin Kharkiv National University, 6 Svobody Square, Kharkiv, 61077; e-mail: v.i.ponomaryov@ukr.net; ORCID: 0000-0003-2513-3187.

(c) Пономарьов Володимир Іванович (Україна) - д.мед.н., професор, завідувач кафедри психіатрії, наркології, неврології та медичної психології медичного факультету Харківського національного університету імені В. Н. Каразіна; пл. Свободи, 6, м. Харків, 61077; e-mail: v.i.ponomaryov@ukr.net; 0RCID: 0000-0003-2513-3187.

(C) Пономарёв Владимир Иванович (Украина) - д.м.н., профессор, заведующий кафедрой психиатрии, наркологии, неврологии и медицинской психологии медицинского факультета Харьковского национального университета имени В. Н. Каразина, пл. Свободы, 6, г. Харьков, 61077; e-mail: v.i.ponomaryov@ukr.net; ORCID: 0000-0003-2513-3187.

(C) Tatyana Roshchupkina (Ukraine) - assistant of the Department of Psychiatry, Narcology, Neurology and Medical Psychology of School of Medicine, V.N. Karazin Kharkiv National University, 6 Svobody Square, Kharkiv, 61077; e-mail: roshchupkina.t@gmail.com; ORCID:0000-0003-3425-2225.

(c) Рощупкіна Тетяна Миколаївна (Україна) - асистент кафедри психіатрії, наркології, неврології та медичної психології медичного факультету Харківського національного університету імені В. Н. Каразіна; пл. Свободи, 6, м. Харків, 61077; e-mail: roshchupkina.t@gmail.com; ORCID: 0000-0003-3425-2225.

(c) Рощупкина Татьяна Николаевна (Украина) - ассистент кафедры психиатрии, наркологии, неврологии и медицинской психологии медицинского факультета Харьковского национального университета имени В. Н. Каразина; пл. Свободы, 6, г. Харьков, 61077; e-mail: roshchupkina.t@gmail.com; ORCID: 00000003-3425-2225.

(C) Oleksandr Mishchenko (Ukraine) - PhD in Medicine, Associate Professor of the Department of Psychiatry, Narcology, Neurology and Medical Psychology of School of Medicine, V. N. Karazin Kharkiv National University, 6 Svobody Square, Kharkiv, 61077; e-mail: alex_mischenk01976@ukr.net; ORCID: 0000-0003-0043-2252.

(с) Міщенко Олександр Миколайович (Україна) - к.мед.н., доцент кафедри психіатрії, наркології, неврології та медичної психології медичного факультету Харківського національного університету імені В. Н. Каразіна; пл. Свободи, 6, г. Харків, 61077; e-mail: alex_mischenko1976@ukr.net; 0RCID: 0000-0003-0043-2252.

(c) Мищенко Александр Николаевич (Украина) - к.М.н., доцент кафедры психиатрии, наркологии, неврологии и медицинской психологии медицинского факультета Харьковского национального университета имени В. Н. Каразина, пл. Свободы, 6, г. Харьков, 61077; e-mail: alex_mischenko1976@ukr.net; ORCID: 0000-0003-0043-2252.

№ 9, 2018, p. 66-71

\section{SOME CLINICAL-THERAPEUTIC FEATURES OF ALCOHOL ENCEPHALOPATHIES}

Abstract.

The article points out that alcoholism for modern society is a significant medico-social problem due to the progressive increase in the prevalence of this disease throughout the world; tendencies to its significant rejuvenation and the large economic, medical, social and other social losses inflicted on society by this disease. The article reveals the main manifestations of the clinical picture of alcohol dependence, which is psycho-neurological symptoms. Also the clinical and therapeutic features of one of the most significant problems of modern psychoneurology - alcoholism and alcohol encephalopathy are outlined. On the basis of literature data, the general principles of the occurrence of this pathology are shown, its main clinical forms with the characteristic of leading symptomatic manifestations are described, the main therapeutic principles of intervention in this problem are revealed. It was stated that during the treatment of acute alcoholic encephalopathy, the etiological factors and concomitant somatic pathology must be taken into account. It was found that the basic eiological mechanisms of action are: - enhancement of microcirculation and improvement of brain metabolism (Cavinton, Trental, Tanacan, Stugeron, Nootropil, Encephabol, etc. are used); - inhibition of platelet aggregation and erythrocytes (using antiplatelet agents - chimes, acetylsalicylic acid, etc.); - conducting hypolipidemic (clofibrate, fenofibrate, nicotinic acid, etc.) and antihypertensive therapy (use of ACE inhibitors (renitec, enap, etc.), Ca antagonists (finoptin, etc.) and beta-blockers (atenolol, etc.)); - correction of psycho-emotional manifestations (use of tranquilizers, antidepressants and anxiolytics); - reduction of mental disorders (use of peptide biostimulants - Cortexin, timogen, epithalamin. The work carried out has led to 
the conclusion that clinical and etiological manifestations, therapeutic mechanisms, types of course and other features of alcoholic encephalopathies, as well as issues of various disorders of the central nervous system, especially higher mental functions in the abuse of alcohol and alcohol-containing substances are extremely important and relevant to modern psychoneurology and addiction problems.

Key words: $\quad$ alcoholism, alcoholic encephalopathy, cognitive impairment.

\section{НЕКОТОРЫЕ КЛИНИКО-ТЕРАПЕВТИЧЕСКИЕ ОСОБЕННОСТИ АЛКОГОЛЬНЫХ ЭНЦЕФАЛОПАТИЙ}

Аннотация. $\quad$ В статье указано, что алкоголизм для современного общества выступает значительной медико-социальной проблемой из-за прогрессирующего увеличения распространености данной патологии во всем мире; тенденции к его значительному омоложению и больших экономических, медицинских, социальных и других общественных потерь, наносимых обществу данным заболеванием. Статья раскрывает основные проявления клинической картины алкогольной зависимости, которую составляет психо-неврологическая симптоматика. Также даны клинические и терапевтические особенности одной из наиболее значимых проблем современной психоневрологии - алкоголизма и алкогольной энцефалопатии. На основе литературных данных показаны общие принципы возникновения этой патологии, описаны ее основные клинические формы с характеристикой ведущих симптоматических проявлений, раскрыты основные терапевтические принципы вмешательства в эту проблему. Констатировано, что при проведении терапии острой алкогольной энцефалопатии обязательно должны учитываться этиологические факторы и сопутствующая соматическая патология. При этом установлено, что базовыми эиологическими механизмами воздействия являются: - усиление микроциркуляции и улучшение метаболизма головного мозга (применяют кавинтон, трентал, танакан, стугерон, ноотропил, энцефабол и др.); - ингибирование агрегации тромбоцитов и эритроцитов (используют антиагреганты - курантил, ацетилсалициловую кислоту и др.); - проведение гиполипидемической (клофибрат, фенофибрат, никотиновая кислота и др.) и антигипертензивной терапии (применение ингибиторов АПФ (ренитек, энап и др.), антагонистов Са (финоптин и др.) и бета-адреноблокаторов (атенолол и др.)); - коррекция психо-эмоциональных проявлений (использование транквилизаторов, антидепрессантов и анксиолитиков); - редукция психических расстройств (применение пептидных биостимуляторов - кортексин, тимоген, эпиталамин. Проведенная работа позволила сделать вывод, что клинико-этиологические проявления, терапевтические механизмы, типы течения и другие особенности алкогольных энцефалопатий, а также вопросы различных нарушений деятельности центральной нервной системы, в особенности высших психических функций при злоупотреблении алкоголем и алкогольсодержащими веществами являются крайне значимыми и актуальными для современной психоневрологии и наркологии проблемами.

Ключевые слова: алкоголизм, алкогольная энцефалопатия, когнитивные нарушения.

ДЕЯКІ КЛІНІКО-ТЕРАПЕВТИЧНІ ОСОБЛИВОСТІ АЛКОГОЛЬНИХ ЕНЦЕФАЛОПАТІЙ.

Анотація.

У статті зазначено, що алкоголізм для сучасного суспільства виступає значною медико-соціальною проблемою через прогресуюче збільшення поширеності даної патології у всьому світі; тенденції до його значного омолодження і великих економічних, медичних, соціальних та інших громадських втрат, що наносяться суспільству даним захворюванням. Стаття розкриває основні прояви клінічної картини алкогольної залежності, яку становить психо-неврологічна симптоматика. Також надані клінічні і терапевтичні особливості однієї з найбільш значущих проблем сучасної психоневрології - алкоголізму і алкогольної енцефалопатії. На основі літературних даних показані загальні принципи виникнення цієї патології, описані ії основні клінічні форми 3 характеристикою провідних симптоматичних проявів, розкрито основні терапевтичні принципи втручання в цю проблему. Констатовано, що при проведенні терапії гострої алкогольної енцефалопатії обов'язково повинні враховуватися етіологічні фактори і супутня соматична патологія. При цьому встановлено, що базовими етіологічнимиі механізмами впливу $є$ : - посилення мікроциркуляції і поліпшення метаболізму головного мозку (застосовують кавінтон, трентал, танакан, стугерон, ноотропіл, енцефабол і ін.); - інгібування агрегації тромбоцитів і еритроцитів (використовують антиагреганти - курантіл, ацетилсаліцилову кислоту та ін.); - проведення гіполіпідемічної (клофібрат, фенофібрат, нікотинова кислота та ін.) і антигіпертензивної терапії (застосування інгібіторів АПФ (ренітек, енап і ін.), антагоністів Са (фіноптин і ін.) і бета-блокаторів (атенолол та ін.)); - корекція психо-емоційних проявів (використання транквілізаторів, антидепресантів і анксіолітиків); - редукція психічних розладів (застосування пептидних біостимуляторів - кортексин, тимоген, епіталамін. Проведена робота дозволила зробити висновок, що клініко-етіологічні прояви, терапевтичні механізми, типи перебігу та інші особливості алкогольних енцефалопатій, а також питання різних порушень діяльності центральної нервової системи, особливо вищих психічних функцій при зловживанні алкоголем і алкогольвмістними речовинами $\epsilon$ вкрай важливими і актуальними для сучасної психоневрології та наркології проблемами.

Ключові слова: алкоголізм, алкогольна енцефалопатія, когнітивні порушення. 
According to the majority of modern authors, alcoholism is a significant medical and social problem of modern society, one of the most complex and extremely dangerous diseases in the world in connection with the emerging huge economic, medical, social, ethical and other social losses. As a result of chronic alcohol intoxication against the background of prolonged abuse of alcohol and alcohol-containing substances, socalled oxidative and nitrosating stress develops, which can lead to significant damage to neurons in the brain, which can be clinically manifested by the development of the so-called neurological deficit and a noticeable decrease in cognitivemnestic functions [1].

Modern world data indicate a progressive increase in the spread of this pathology among the countries of the world community, moreover, there is a significant tendency worldwide for a permanent rejuvenation of this pathology [2]. A significant concern is the fact that among countries which are in the first positions on alcohol consumption, more than a third of the working-age male population systematically abuses alcohol and alcohol-containing substances in extremely dangerous dosages, which causes the development of a number of somatic diseases associated with alcohol intoxication first of all the psychoneurological profile) [3]. According to the estimates of the world's scientists, somatic pathology in people with alcohol dependence is found 12 times more often than the average in the population [4]. One of the most severe and significant consequences of alcohol dependence is the possible development of so-called comorbidity - somatoneurological and psychopathological complications of the actual addictive disorder [5].

According to most modern authors, psychoneurological symptoms form the basis of the clinical picture of alcohol dependence. The development of gross dementive manifestations in patients with alcohol dependence is preceded by mild (moderate and mild) cognitive impairments, which do not cause severe medical and social disadaptation of patients, which causes great diagnostic difficulties in detecting the so-called alcoholic encephalopathy (occurs most often after prolonged abuse of alcohol and alcoholcontaining substances), especially at the initial stages of pathology development.

Alcoholic encephalopathy belongs to the group of alcoholic psychoses that arise following prolonged chronic abuse of alcohol and alcoholcontaining substances, in the setting of which there is a combination of mental disorders with systemic somato-neurological disorders (very often they are dominant in the clinical picture of the disease). In most cases, the development of alcoholic encephalopathies occurs after years of massive abuse of alcohol and alcohol-containing substances, the duration of which is noted from 5 to 20 years.

Encephalopathies are polyethiologic diseases characterized by the presence of nonspecific and specific symptom-complexes. Encephalopathies may be acute and chronic, as well as atypical and typical [6].

As many authors have noted, the most common form of encephalopathy is alcoholic encephalopathy. In accordance with the classification of G.V. Morozov, the following groups of acute and chronic alcoholic encephalopathies are distinguished:

Acute forms: Gaye-Wernicke, mitigated form, hyperacute form.

- Chronic forms: Korsakov's psychosis; alcoholic pseudo-paralysis; alcoholic encephalopathy caused by stenosis of the superior vena cava; alcoholic encephalopathy of Marciyafavy-Benyam, alcoholic pellagra, Morel's disease, alcoholic encephalopathy with the picture beriberi, alcoholic encephalopathy with retrobulbar neuritis, alcoholic cerebellar atrophy, central necrosis of the bridge of the brain.

Acute alcoholic encephalopathy of GayeWernicke is characterized by a progressive increase in various somato-psychoneurological disorders and exacerbation of concomitant diseases (hepatitis, pancreatitis, etc.). In some patients this form lasts for months, for others it takes several weeks. Characterized by the presence of significant weakness, dyspnea and arrhythmia, frequent headaches and pains in the limbs; progression of neurological symptoms (tremor of limbs, stiffness of movements, coordination disorders, etc.); patients complain of feelings of fear, panic, anxiety; sleep disturbances (nightmares, sleep instability) and muscle tone; vegetative changes (increase in body temperature, increased sweating); there is a violation of consciousness (stunning, sopor and coma).

Mitigated acute alcoholic encephalopathy is characterized in some patients by somnolence in the daytime and by mild delirious symptoms in the night; and in others - a depressed-dysphoric mood and the presence of hypochondriacal manifestations. At the same time, there are minor somato-neurological disorders.

Hyperacute alcoholic encephalopathy is characterized by the presence of professional or exaggerating delirium and massive somatoneurologic symptoms. There is a sharp increase in temperature to febrile figures $\left(40-41^{\circ} \mathrm{C}\right)$. The course of the manifest stage is lightning quick. For one or several days, there is a development of coma and a lethal outcome on the $2-5^{\text {th }}$ day of the disease.

Many authors consider mitigated acute alcoholic encephalopathy and hyperacute alcoholic encephalopathy as subtypes of acute alcoholic encephalopathy of Gaye-Wernicke. 
At this point in time, Korsakov's psychosis is very rare and can occur after severe delirium and alcoholic encephalopathy of Gaye-Wernicke. This type of encephalopathy is most often found in patients aged $40-50$ years, occasionally at 50-60 and up to 30 years. In this case, this form is characterized by the presence of amnesia, disorientation in place and time and confabulation. The disease proceeds in a regrendent manner, a significant improvement in the condition is more often observed in women than in men.

Alcoholic pseudo-paralysis, according to various authors, is most often found in males in a mature and later age. Its development occurs after severe delirious states and encephalopathy of Gaye-Wernicke against a background of markedly progressive alcoholic degradation of personality. Patients are noted for lack of criticism, passivity, inactivity, positive emotional background and gross memory disorders [7].

Alcoholic encephalopathy, which is caused by stenosis of the superior vena cava (was described by Frederichs in 1877 and Lansceraux in 1899). It appears in patients with alcoholic cirrhosis of the liver and is characterized by acute disorders of consciousness. There is a presence of euphoria with «childish» behavior, playfulness, irritability and apathy. A characteristic symptom complex is the presence of hypotension with a small tremor of the fingers. Attacks of disorders are observed from 24 to 48 hours and have a reversible character.

Alcoholic encephalopathy of MarietaafaBenjami (the so-called central degeneration of the corpus callosum) was described by E. Marchiafava and A.Bignami in 1903. Clinically, it resembles a severe, rapidly progressive alcoholic personality degradation that is followed by severe dementia. These manifestations are joined by symptomatic, lasting from several days to 2-3 months symptomatology of psychosis (stunning of various degrees, severe delirious disorders, manifestations of pseudoparality or Korsakov syndrome). Emerging mental disorders have a significantly deeper level (manifestations of pseudo-paralytic syndrome, the presence of gross memory disorders with fixative amnesia and confabulation) and irreversible character.

Morel's disease (the so-called cortical laminar sclerosis) begins with severe delirium, the manifestations of which are similar to the encephalopathy of Gaye-Wernicke. After the disappearance of the manifestations of delirium, the symptom complex characteristic of the dementia form of progressive paralysis is characteristic. This form was first described in 1939 by the pathologist F.Morelem. As most authors note, very often Morel's disease develops in combination with alcoholic encephalopathy Marciafava-Binyamy (arises from the degeneration of the corpus callosum against the abuse of alcohol and alcohol-containing substances).
Alcoholic encephalopathy with a picture of beriberi is manifested against the background of insufficiency of vitamins of group B (mainly B1). Clinically manifested primarily neurological disorders and asthenic manifestations.

Alcoholic encephalopathy with the symptom complex of retrobulbar neuritis can occur both in isolation and in combination with other forms of alcoholic encephalopathy. Clinically, it is represented by various asthenic manifestations.

Alcoholic cerebellar atrophy (described by J.Lhermitte in 1934) is characterized by degeneration of the cerebellar cortex and, mainly, occurs in men 35-65 years old. It is manifested by organic and asthenic disorders of varying severity.

Central necrosis of the bridge (first described in 1959 by R.Adamsom) is characterized by the presence of an apathetic stupor, manifestations of indifference and detachment from the surrounding world, the lack of response to pain stimuli.

As many modern authors note, alcoholic encephalopathy is inherently the final stage of alcohol dependence, which is characterized by constantly worsening degradation of the personality with the defeat of all levels of its existence: both physical and psycho-social [8], which develops in most cases at the age of 45-50years after prolonged (15-20 or more years) abuse of alcohol and alcohol-containing substances [9].

Another important issue in the practice of managing patients with alcoholism with signs of alcoholic encephalopathy is the problem of therapeutic intervention. As the experience of studying modern world literature shows, approaches to the therapy of patients at the stage of development of alcoholic encephalopathy have considerable difficulties. Most researchers are of the opinion that it is necessary to develop special individual therapeutic programs for treating such patients [10]. Also clinicians pay special attention to the presence of certain features of the process of treatment of patients in the final stage of alcohol dependence with the presence of alcoholic encephalopathy. Treatment of such patients as a rule should be carried out in stationary conditions because of the significant severity of the patient's condition and the presence of accompanying polyorganic gross violations [11]. At the same time, it is necessary to pay attention to the fact that before the beginning of the specific anti-alcohol therapy such patients should undergo a thorough somatoneurological diagnosis, and in most cases consult specialists of another profile (psychiatrist, neuropathologist, therapist, surgeon, etc.).

Modern therapeutic suppression of a pathological desire to use alcohol and alcoholcontaining substances is a complex process. The development and implementation of pathogenetically substantiated medication in suppressing the pathological desire to use alcohol 
and alcohol-containing substances is based on current available ideas about the pathogenetic mechanisms that arise in the presence of alcohol dependence $[12 ; 13]$.

According to the available ideas, the biochemical basis of alcohol dependence is the specifically altered metabolism of catecholamines (directly dopamine) of limbic and thalamic morphofunctional brain systems. The development of pathological attraction to alcohol-containing substances and alcohol is determined by the existing imbalance of the following neurotransmitter systems of the body: adrene, dopamine and serotoninergic and the system of endogenous opiates (associated with the dopaminergic system and responsible for alcohol-induced psychotropic effects) [14].

Proceeding from this, the following psychotropic drugs are used to actively influence the key links in the pathogenesis of alcohol dependence: antipsychotics, antidepressants, anticonvulsants, tranquilizers, nootropics, which constitute the so-called group of "anticravings» $[15 ; 16]$. The duration of active use of these drugs in the final stage of the disease lasts about 1.5-2 months, which contributes to the stabilization of the mental state of patients with alcohol dependence [17]. One should take into account that the age factor may have a negative effect on the effectiveness of this therapy [8]; At the same time, organic (cerebrovascular) changes, hepatic functional disorders, weakening of the compensatory and adaptive capabilities of the organism, can, on the contrary, increase the sensitivity of the nervous system of patients with alcohol dependence to the effects of medicinal substances [18].

After an intensive course of therapy, as a rule, patients undergo a stage of maintenance therapy lasting up to 5 years [19].

As for the representatives of the abovementioned applied groups of drugs, it should be noted the priority use of drugs from the group of antidepressants in the clinical practice of alcoholism treatment due to the close relationship of pathological attraction to alcohol and alcoholcontaining substances and the presence of affective disorders. In the treatment of the final stage, tricyclic antidepressants (amitriptyline, melipramine, ludomyl, lerivone, etc.) are mainly used $[20 ; 21]$.

Among the group of anticonvulsants, finlepsin is most often used (it is most effective if the patient has impulsiveness and dysphoric affect, an insurmountable "attraction» to alcohol, the absence of a «struggle of motives», which clinically brings this condition closer to paroxysms).

In addition to the drugs that have a direct psychotropic effect on the pathological link of the "unrestrained» craving for alcohol and drug-containing substances, the drugs that form psychotropic effects indirectly (nootropics, vitamins, metabolic stimulants, antioxidants, etc.) are used in the treatment of the final stage of alcohol dependence.

To stop one of the main obligate manifestations of the final stage of alcohol dependence (chronic encephalopathy with deficient psychoorganic disorders and persistent asthenia), drugs from the nootropic group are used (their maximum effectiveness is determined by the impact on the clinic of the existing psycho-organic syndrome, intellectual-mnestic depression, asthenic and asthenic-depressive disorders ). Also in therapy, vitamins (mainly group «B»), amino acids, metabolic stimulants and antioxidants are actively used; those having significant influence on the process of reduction of the «unrestrained» craving for alcohol and having a positive effect on the consequences of the action of ethanol.

For the treatment of one of the most frequent and formidable complications of chronic alcohol and alcohol substance abuse (alcoholic encephalopathy), combined medication regimens are used, consisting of neuroleptics, tranquilizers, nootropics, vitamins, anxiolytics, antidepressants, and others.

As a rule, acute alcoholic encephalopathy is manifested by delirium with a variety of psychotic symptoms. In this case, psychocorrective intervention consists of the use of high doses of neuroleptics and tranquilizers, which causes an aggravation of cognitive impairment.

With the aim of couping of the existing psychomotor excitation, tranquilizers (relanium, rohypnol, reladorm, etc.) are used in combination with sodium oxybutyrate; acute psychotic manifestations with the presence of psychomotor excitation are stopped by applying $1.0-2.0 \mathrm{ml}$ of a $0.5 \%$ solution of haloperidol; for «removing» acute conditions $20.0 \%$ solution of nootropil in / in $2.0-6.0 \mathrm{~g} /$ day for $10-15$ days is used. In addition, it is common to use massive doses of vitamin B1 (at the beginning of therapy to $1 \mathrm{~g}$ per day) as a pathogenetic therapy (IV 5.0 to $5.0 .0 \mathrm{ml} 6.0 \%$ thiamine bromide with $10.0-15.0 \mathrm{ml} 40.0 \%$ glucose solution 1-3 times a day in complex with vitamin C and nicotinic acid). The course of vitamin therapy lasts at least 2-3 months (in the beginning, shock doses are used for 10-15 days, after which the dosage is gradually reduced). Also it is mandatory to use hepatoprotectors (essential-forte, carp) and lipotropics.

According to available data on the nature of mnestic disorders on the background of prolonged abuse of alcohol and alcoholcontaining substances and their relationship with the disruption of the functioning of serotonergic neurons, many authors propose to use selective serotonin inhibitors in the treatment of acute alcoholic encephalopathy, for example, fluvoxamine at $200.0-250.0 \mathrm{mg}$ in day. 
Thus it is necessary to take into account, that the conducted therapy for an acute alcoholic encephalopathy necessarily should be carried out taking into account etiological factors and accompanying somatic displays. The basic etiological mechanisms of exposure are:

- increase in microcirculation and improve brain metabolism (apply cavinton, trental, tanakan, stugeron, nootropil, encephabol, etc.);

inhibition of platelet aggregation and erythrocytes (antiplatelet agents - curantyl, acetylsalicylic acid, etc.);

- carrying out (clofibrate, fenofibrate, nicotinic acid, etc.) and antihypertensive therapy (use of ACE inhibitors (renitek, enap, etc.), antagonists of Ca (phinoptin, etc.) and beta-blockers (atenolol, etc.);
- correction of psycho-emotional manifestations (use of tranquilizers, antidepressants and anxiolytics);

- reduction of mental disorders (use of peptide biostimulators - cortexin $(0.01 \mathrm{~g}$ per day), thymogen $(0.01 \%$ solution per $1 \mathrm{ml} \mathrm{IM}$ in the morning), epithalamine ( $0.01 \mathrm{~g}$ per day for 10 days).

Thus the clinical and etiological manifestations, therapeutic mechanisms, flow types and other features of alcoholic encephalopathies, as well as the various disorders of the central nervous system, especially the higher mental functions in the abuse of alcohol and alcohol-containing substances, are extremely significant and relevant for modern psychoneurology and narcology problems [23; 24].

\section{References}

1. Соколик Е. П. Фармакокоррекция нейропептидами нитрозирующего стресса и неврологических нарушений при экспериментальной алкогольной интоксикации / Е. П.Соколик, А. Н. Егоров // Материалы XII-ой открытой итоговой науч.-практ. конф. студентов и молодых ученых с междунар. участием «Молодежь и медицинская наука в XXI веке», 30 марта - 1 апреля 2011 года г. Киров. - Киров: КГМА, 2011. - С. 82

2. Ютен К. Что такое наркологическое заболевание / К. Ютен // Наше здоровье: журн. Американского союза здравоохранения. - 2001. - Т. 9, № 1. - С. 4-8.

3. Огурцов П. П. Острые отравления этиловым спиртом. Злоупотребление алкоголем в России и здоровье населения. Острые отравления этиловым спиртом и его сурогатами: инф. материалы и рек. для врачей / П. П. Огурцов, В. П. Нужный. - М., 2000. - С. 113-155.

4. Савельев, Д. В. Сравнительная характеристика синдрома отмены у больных алкоголизмом в г. Москве в 1965, 1985, 2005 гг. / Д. В. Савельев, Е. М. Новиков, А. Н. Булатников // Вопр. наркологии. - 2007. - № 3. - С. 33-43.

5. Медико-социальные и экономические последствия злоупотребления алкоголем в Российской Федерации / Е. А. Кошкина, Н. И. Павловская, Р. И. Ягудина [и др.] // Информационно-аналитический сб. «Социальные аспекты здоровья населения». - М., 2010. - С. 2.

6. Павлова Т. М. Частота выявления соматической патологии при алкогольной зависимости / Т. М. Павлова, О. Ж. Бузик, М. А. Иванова // Социальные аспекты здоровья населения. - 2010. - С. 1-5.

7. Гофман А. Г. Клиническая наркология / А. Г. Гофман. - 2-е изд. - М.: Медицинское информационное агентство, 2017. - 376 с.

8. Чирко В. В. Очерки клинической наркологи / В. В. Чирко, М. В. Демина. - М.: Медпрактика, 2002. - 238 с.

9. Иванец Н. Н. Алкоголизм: рук-во для врачей / Н. Н. Иванец. - М.: Медицинское информационное агентство, 2011. - 856 с.

10. Алкогольная и наркотическая зависимость: практич. рук-во для врачей / Г. М. Энтин, А. Г. Гофман, А. П. Музыченко, Е. Н. Крылов. - М.: Медпрактика-М, 2002. - 328 c.

11. Петушков Е. Р. Своеобразие клиники и особенности течения хронического алкоголизма у больных позднего возраста / Е. Р. Петушков // Неотложные со- стояния в наркологи: под ред. проф. Б. Д. Цыганкова. - М.: Медпрактика-М, 2002. - С. 35-38.

12. Принципы лечения психотропными средствами больных эндогенными заболеваниями, сочетающимися с алкоголизмом: пособ. для врачей / А. Г. Гофман, Н. В. Александрова, А. В. Граженский [и др.].- М., 1997. - 24 c.

13. Erickson C. K. Review of neurotransmitters and their role in alcoholism treatment / C. K. Erickson // Alcohol \& Alcoholism. - 1996. - Vol. 13, Suppl. 1. - P. 5-11.

14. Буров Ю. В. Возможное значение эндогенной опиатной системы в формировании влечения к алкоголю / Ю. В. Буров, В. Н. Жуков, С. А. Борисенко // Нейрофизиология. - Л., 1980. - С. 28-29.

15. Музыченко А. П. Ноотропные препараты в психиатрической практике / А. П. Музыченко // Труды VI Российского национального конгресса «Человек и лекарство».- М.: ГОЭТАР Медицина, 1999. - С. 345-358.

16. Sowers W. Psychotropic medication management in persons with co-occurring psychiatric and substance use disorders / W. Sowers, Sr. Golden // J. Psychoact. Drugs. - 1999. - Vol. 31, № I. - P. 59-70.

17. Малин Д. И. Побочное действие психотропных средств / Д. И. Малин.- М.: Вузовская книга, 2000. 208 C.

18. Винникова М. А. Течение наркологических заболеваний в позднем воздасте / М. А. Винникова // Депрессия в наркологии. Особенности клиники и терапии алкогольной зависимости у больных пожилого возраста. - 2003. - С. 2-7.

19. Шабанов П. Д. Основы наркологии / П. Д. Шабанов. - СПб.: «Лань», 2002. - 555 с.

20. Наркология. Национальное руководство // ГЭОТАР-Медиа: под ред. Н. Н. Иванца, И. П. Анохиной, М. А. Винниковой. - 2008. - 720 с.

21. Иванец Н. Н. Современная концепция терапии наркологических заболеваний / Н. Н. Иванец // Вопр. наркологии. - 2013. - № 1. - С. 108-118.

22. Иванец Н. Н. Лечение алкогольной зависимости / Н. Н. Иванец, М. А. Кинкулькина // Психиатрия и психофармакотерапия. - 2001. - Т. 3, №. 3. - С. 80-82.

23. Alwan A. Global strategy to reduce the harmful use of alcohol / A. Alwan // Доклад BO3. - 2010. - 48 с.

24. Шишонкова О. Н. Клинико-патогенетические и терапевтические аспекты алкогольных энцефалопатий / О. Н. Шишонкова // Вісн. психіатрії та психофармакотерапії. - 2012. - № 1 (21). - С. 102-107. 